\title{
The Issue of Updating the Real Estate Cadastre in the Field of Land Use in Connection with the Construction of a Building
}

Abstract: $\quad$ From the year 2014 to July 31, 2020, setting out a building was surveying work subject to the obligation to report to the locally competent district governor (starost) before it was commenced. After completion of the building setting out, the contractor of surveying works was obliged to notify the authorities of the completion of the surveying works and to submit the results of surveying works connected with the building setting out. Since July 31, 2020, following the amended Geodesic and Cartographic Law, the obligation to report the building setting out has been repealed. Despite that, the real estate owner will still be obliged to submit an appropriate application to the starost to disclose the new land use in accordance with Article 22 of the Geodesic and Cartographic Law.

The author has analysed 31 documentation sets, being the results of building setting out procedures. The analysis verified the size of a land parcel on which the buildings were set out, what land use was presented before setting out and what land use was presented after the building setting out. In addition, the current state of development of the land parcel (as of July 2020) was examined using map portals, and an orthophotomap was used to check whether the building was constructed, in order to verify whether the real estate cadastre was updated further.

Keywords: land use, building setting out, real estate cadastre

Received: 12 October 2020; accepted: 16 November 2020

(C) 2021 Author. This is an open access publication, which can be used, distributed and reproduced in any medium according to the Creative Commons CC-BY 4.0 License.

1 Warsaw University of Technology, Poland, email: m.karabin-zych@pw.edu.pl, ORCID ID: https://orcid.org/0000-0002-9522-0449 


\section{Introduction}

Until 31 July, 2020, building setting out was one of the surveying works that had to be reported by the contractor to the locally competent district starost before it was started. As of 31 July 2020, this obligation was repealed in connection with the amendment of the Act [1]. Within the scope of the obligation to provide the documentation constituting the result of the building setting out, and the notification of the completion of those surveying works, the legislator assumed two possibilities. Pursuant to Article 12c of the Act [1], prior to the amendment, if within a period not longer than 30 days from the date of setting out of construction objects, documents presenting results of as-built geodetic inventory of those objects were submitted to the state geodetic and cartographic resource, the contractor of surveying works was not obliged to notify of the completion of those works and to submit the results of the surveying works related to the building setting out. On the other hand, if the as-built inventory of the building was carried out later, such a notification should have been made and the documentation constituting the result of building setting out should have been submitted.

The paper will present the analysis of 31 sets of documentation being the result of setting out buildings (9 from the area of Mińsk district, 9 from the area of Nowy Dwór district, 13 from the area of Warsaw West district). This analysis will concern the aspect of determining the type and range of land use at the stage of building setting out. Moreover, the current state of land parcel/parcels development (as of July 2020) was examined on the basis of the orthophotomap available on Geoportal, the basic map and cadastral map available on map portals of individual districts, in order to check what land use types and ranges were determined at a later stage and whether the land and buildings register had been updated.

\section{Effects of the Building Setting Out}

In accordance with Article 41.1 of the Act [2], construction starts as soon as preparatory works on the construction site are commenced. Such preparatory works include the setting out of objects in the field.

As reads Article 43.1 of the Act [2], construction objects requiring a building permit and objects specified in Article 29.1.1a, 2b and 19a-20b are subject to geodetic delineation in the field, and after their construction to an as-built geodetic inventory, including their location on the ground.

Given that once a building has been set out this means that construction has started in the land and buildings register, it would be necessary to indicate the land from the group of built-up and urbanised land, being urbanised, not built-up land or land under development, marked with the symbol - Bp. 
This is because, according to Annex 6 to the Regulation [3], urbanised, not built-up lands or lands under development includes:

1) lands on which construction has started but has not been completed, according to the meaning of Article 41(1) of the Act of 7 July 1994 - The Building Law, resulting in the exclusion of such lands from agricultural or forest production, according to the meaning of the Act of 3 February 1995 on protection of agricultural and forest lands;

2) lands which, as a result of development, have been excluded from agricultural or forest production according to the meaning of the provisions of the Act of 3 February 1995 on the protection of agricultural and forest land, but on which pre-existing buildings have been demolished, and at the same time the lands are planned for development.

Despite the repeal of the surveyor's obligation to report the setting out as of July 31 2020, the real estate owner will be still obliged to report changes in the land and buildings register data in connection with the commencement of construction. According to Article 22 of the Act [1], real estate owners shall report changes in the data included in the land and buildings register to the appropriate district starost within 30 days from the date when those changes took place. This obligation does not apply to changes in the data covered by the land and buildings register, resulting from normative acts, valid court decisions, administrative decisions, notarial acts, resource materials, entries in other public registers and architectural-and-building documentation maintained by the architectural-and-building authorities. However, there are doubts in such cases as to whether the land and buildings register should be updated following the application of the real estate owner or ex officio. Opinions on that issue are divided. Following the Judgment of the Voivodeship Administrative Court in Wrocław [4], if a decision has been issued to exclude lands from agricultural and forest production, the land and buildings register should be updated ex officio.

Since the land use in the land and buildings register (the real estate cadastre) is changed, the surveyor should develop a list of changes in the cadastral data and append it to the technical documentation file (before the amendment of the Act [1] to the building setting out documentation). According to $\S 46.3$ of the Regulation [3], the list should include:

1) identification of the cadastral unit and district;

2) the number of the relevant land registration unit or the number of a building file item;

3) the land and mortgage register number;

4) designation of the cadastral database object whose cadastral data have been changed;

5) existing cadastral data and data established as a result of performed surveying works; 
6) the date of the drawing up the list;

7) the name and the surname or the company name of the contractor and signature of a person representing the contractor;

8) the name and the surname and the signature of the person who drew up the document and the date of its preparation;

9) the name and the surname and the signature of the manager of surveying works, if any;

10) the number of certified surveyor's qualifications of the person who drew up the document or the number of certified surveyor's qualifications of the manager of surveying works.

By 31 July 2020, after the completing works related to setting out of building objects, the contractor of surveying works was obliged to notify about the completion of surveying works and to submit the results of those surveying works related to buildings setting out.

The cadastral register was updated which, in accordance with $\S 45$. 1 of the Regulation [3], is performed by introducing documented changes to the register database in order to:

1) replace data which does not comply with the real conditions, the legal status or applicable technical standards;

2) replace data with relevant data in accordance with the real or legal conditions and the applicable technical standards;

3) disclose new cadastral data;

4) eliminate incorrect data.

In order disclose the changes in the real estate cadastre, a relevant application must be submitted, because - as stated in Article 24.2a of the Act [1] - the information contained in the land and buildings register is updated:

1) ex officio, if changes of information result from:

a) the legal regulations,

b) the documents referred to in Article 23(1) to (4),

c) materials from the geodetic and cartographic resources,

d) detection of incorrect information;

2) at the request of the entities referred to in Article 20 item 2 point 1 (i.e. owners of real estate's), or those who own land on the principles of self-possession.

After the building has been constructed, a geodetic as-built inventory should be performed.

Within the framework of the documentation being the technical documentation of the as-built geodetic inventory of the building, the surveyor prepares, among others, a list of changes in the cadastral data concerning the land parcel in order to present the new type of land use (if the use changes) and a list of changes in the cadastral 
data of the building in order to present the constructed building. As far as the land use type is concerned, the provisions of Annex 6 to Regulation [3] should be taken into account. As in the case of a building, for changes to be disclosed in the real estate cadastre, an application must be submitted (under Article 24.2a of the Act [1]). As research shows, the application is often not attached to the documentation because surveyors believe that the changes should be introduced ex officio. The authors of [5] have highlighted this problem.

\section{Exclusion of Lands from Agricultural and Forest Production}

According to the Act [6], the exclusion of land from production means the commencement of non-agricultural or forestry land use. As stated in Article 11.1 exclusion from production of agricultural land created from mineral and organic soils in classes I, II, III, IIIa, IIIb, as well as agricultural lands in classes IV, IVa, IVb, $\mathrm{V}$ and VI created from organic soils, and lands under fishponds and other water bodies exclusively used for agricultural purposes, lands under residential buildings on farms and other buildings and installations exclusively used for agricultural production and food processing, lands under buildings and equipment used directly for agricultural production considered as a special division, in accordance with provisions on personal and corporate income taxes, rural parks, and lands under forests and bushes in the fields, including lands under wind belts and anti-corrosion facilities, family allotment gardens and botanical gardens, lands under installations used for water drainage, flood and fire protection, agricultural water supply, sewage and waste water and waste disposal for agriculture and rural residents, lands reclaimed for agriculture, peatbogs and water bodies, lands under access roads to agricultural lands and forest lands intended for non-agricultural and non-forestry purposes - this may take place after decisions authorising such exclusion have been taken. The decision shall specify the relevant obligations associated with the exclusion. The decision shall be issued before the building permit is obtained.

As stipulated in Article 12.1 of the Act [6], a person who has been authorised to exclude land from agricultural production is obliged to pay an annual fee and charges and, in the case of forest land, a one-off compensation in the event of premature felling of trees. Such an obligation arises on the date of the actual exclusion of land from production. In accordance with Article 12a of the Act [6], this obligation does not apply to the exclusion of land from agricultural or forest production for housing purposes:

1) up to 0.05 ha for a single-family building;

2) up to $0.02 \mathrm{ha}$, for each dwelling, in the case of a multi-family building.

Most often, decisions are made regarding the exclusion of lands from agricultural and forest production for housing purposes. This is confirmed by the author's research in numerous publications [7-9]. 
Exclusion of land from the agricultural and forest production is aimed at protecting such land, in particular against the use of the best-quality land for investment purposes. As the authors of [10] write,

in practice, the area exempt from the fee $\left(500 \mathrm{~m}^{2}\right.$ for single-family homes and $200 \mathrm{~m}^{2}$ for each place in the case of multi-family houses) is too small. Remaining after excluding the parcels of $1000 \mathrm{~m}^{2}$ and $1500 \mathrm{~m}^{2}$ of land no longer serve for agricultural production. The frequent disclosure that the rest of the plot is agricultural land is often fictional in this case.

\section{Problems of Determining the Range of Land Use}

When the surveyor indicates a new use in the land and buildings register, its extent must also be specified in addition to the type. Annex 6 to the Regulation [3] states that when determining the limits of urbanised land that is not built-up or is in the course of development, the provisions of decisions authorising the exclusion of land from agricultural or forest production (issued pursuant to Articles 11 and 28.2 of the Act [6]) and the content of the parcel development plan for the parcel or land referred to in Article 34.3(1) of the Act [2] must be taken into account, applying the rules for the determination of the limits of residential, industrial and other built-up areas, respectively. Table 1 lists the characteristics of the land and other conditions which determine the classification of lands as residential areas, industrial areas and other built-up areas, resulting from Annex 6 to the Regulation [3].

Table 1. List of land characteristics and other conditions which determine the classification of lands into particular land uses

\begin{tabular}{|c|c|c|}
\hline Item & $\begin{array}{l}\text { Type and specification } \\
\text { of land use }\end{array}$ & $\begin{array}{l}\text { The characteristics of the land and other conditions that } \\
\text { determine the classification of land into individual uses }\end{array}$ \\
\hline 1 & Housing areas $-\mathrm{B}$ & $\begin{array}{l}\text { Housing areas include land which is not part of the habitat } \\
\text { plots referred to in item } 5 \text { : } \\
\text { 1. occupied under buildings classified in PKOB under } \\
\text { Division } 11 \text { - residential buildings; } \\
\text { 2. occupied for farm and technical buildings, functionally } \\
\text { related to the residential buildings referred to in point } \\
\text { 1, and installations, in particular: yards, access roads, } \\
\text { passageways, home playgrounds, playgrounds and resting } \\
\text { places, wells, reservoirs, over ground pipes, sewage } \\
\text { collection and treatment facilities, rubbish bins, landfills, } \\
\text { small architecture objects, fences, ponds, rock gardens; } \\
\text { 3. located between or in the immediate vicinities of buildings } \\
\text { and facilities referred to in points } 1 \text { and } 2 \text { and not used } \\
\text { for any other purpose that would justify their inclusion } \\
\text { in another group of land use, including areas occupied by } \\
\text { lawns, flower-beds and vegetables }\end{array}$ \\
\hline
\end{tabular}


Table 1. cont.

\begin{tabular}{|c|c|c|}
\hline 2 & Industrial areas $-\mathrm{Ba}$ & $\begin{array}{l}\text { Industrial areas include lands: } \\
\text { 1. occupied by buildings, included in PKOB group } 125 \text { - } \\
\text { industrial and storage buildings, and related structures } \\
\text { and equipment, in particular: shelters, boiler houses, } \\
\text { reservoirs, over ground pipes, storage yards, parking } \\
\text { and manoeuvring yards, fences, bins, landfills; } \\
\text { 2. located between or in the immediate vicinities of buildings, } \\
\text { structures and equipment referred to in point } 1 \text { and not } \\
\text { used for any other purpose that would justify their } \\
\text { inclusion in another group of land use, including lands } \\
\text { occupied for flower-beds; } \\
\text { 3. occupied for transport and renovation bases, transformer } \\
\text { stations, above-ground pipelines, collectors and water } \\
\text { supply lines, refuse dumps and dumps, water intakes } \\
\text { and sewage treatment plants }\end{array}$ \\
\hline 3 & Rother built-up areas - Bi & $\begin{array}{l}\text { Other built-up areas include lands: } \\
\text { 1. occupied for buildings and structures other than } \\
\text { those included in PKOB division } 11 \text { and group } 125 \\
\text { and equipment related to those buildings and structures, } \\
\text { in particular: boiler rooms, tanks, over ground pipes, } \\
\text { storage yards, parking and manoeuvring yards, fences, } \\
\text { bins, landfills; } \\
\text { 2. located between or in the immediate vicinities of buildings, } \\
\text { structures and equipment referred to in point } 1 \text { and not } \\
\text { used for any other purpose which would justify their } \\
\text { inclusion in another group of land use, including lands } \\
\text { occupied for flowerbeds, } \\
\text { 3. occupied by active and inactive cemeteries, but not } \\
\text { included in wooded and bushed land, and animal burial } \\
\text { grounds }\end{array}$ \\
\hline
\end{tabular}

Source: Annex 6 to the Regulation [3]

In order to obtain a decision allowing the land to be excluded from agricultural or forest production, the investor must submit a relevant application to the district starost, one of the appendices of which is a land parcel development plan with a graphically marked and calculated area to be excluded from production, together with the designed building. A decision is issued on the basis of that application; it allows the land to be excluded from agricultural or forest production and contains information about the parcel size which is to be excluded.

As the authors [11] write, "the act does not specify the rules for determining the boundary of the exclusion area, nor the distance of this boundary from the designed building, nor the requirements as to its shape". Since the fees for the exclusion are quite high, in the case of excluding land from agricultural or forestry production for housing construction, designers create the border of the area to be excluded in such a way that the conditions contained in Article 12a Act [6] are fulfilled. This is also indicated by the authors [12-14]. 
As the authors [11] point out, "this border sometimes runs alongside or at a short distance from the walls of the building or other permanent elements of land development, e.g. sidewalks". This problem is also indicated in [15].

The land parcel development plan includes information on the land balance sheet, which specifies, among others, the area of development to be excluded from agricultural or forest production and the biologically active area resulting from the local land development plan. In accordance with $\S 3$ point 22 of the Regulation [16], a biologically active area should be understood as an area which surface has been arranged in such a way that it ensures natural vegetation of plants and rainwater retention, as well as $50 \%$ of the area of terraces and roofs with such a surface and other areas ensuring natural vegetation of plants, with an area of not less than $10 \mathrm{~m}^{2}$, with surface water in the area.

Taking into account the above provisions, the surveyor has to determine the extent of the land use. When determining the range of Bp land use limits, the surveyor must take into account the whole of the planned development of the land parcel assuming the Bp land use limits occupied by buildings, stairs, terraces, any hardening or covered with concrete. Figure 1 shows an exemplary land parcel No. 111, which area equals to 0.1311 ha and a marked area to be excluded from agricultural production of the size of 0.0459 ha, in connection with the construction of a single-family residential building.

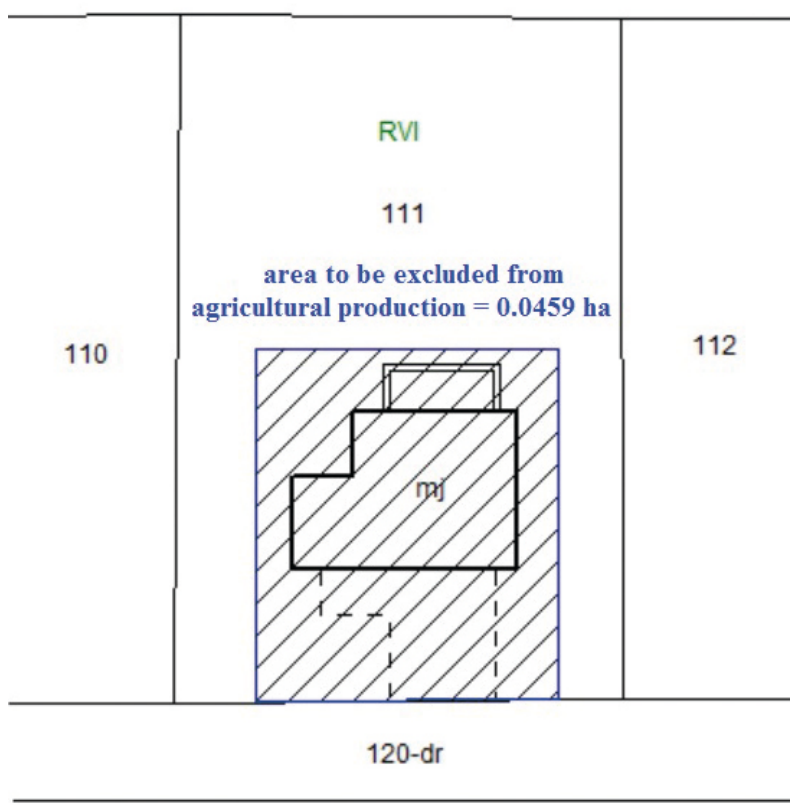

Fig. 1. Land parcel 111 - area to be excluded from agricultural production 
In Figure 2, the limits of use Bp were adopted in accordance with the decision to exclude from agricultural production. This solution is indicated by J. Bielański [17], who states that the part of the land parcel, for which the owner has obtained the permission to be exclude it from production, a new Bp use should be presented instead of the existing one, e.g. R.

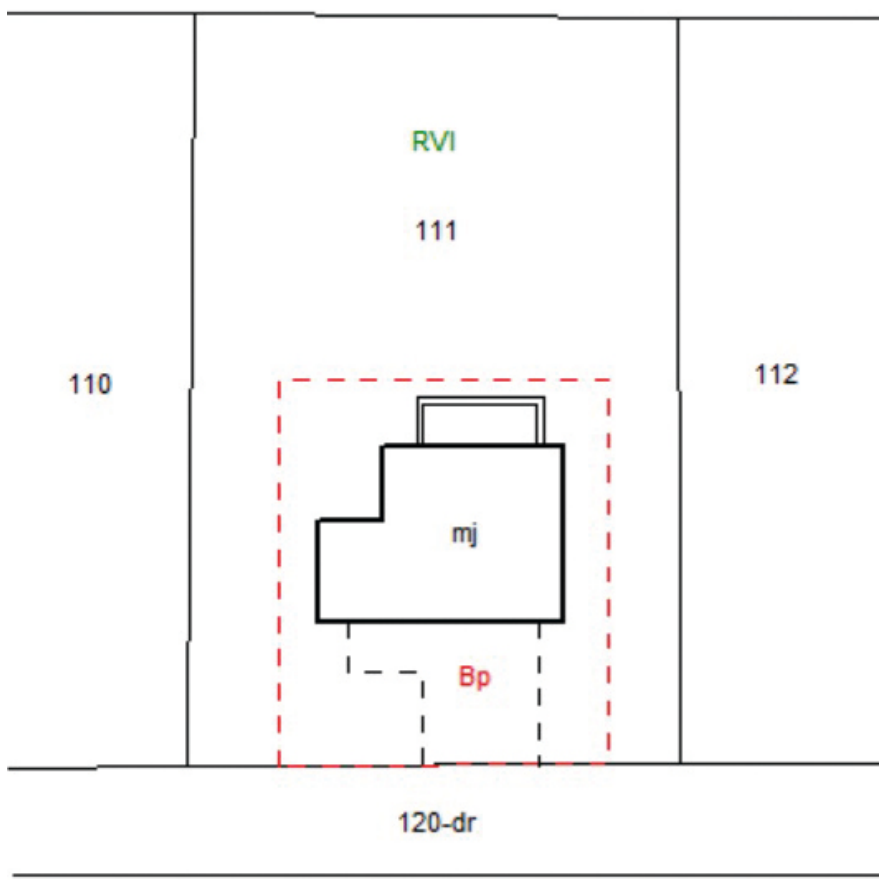

Fig. 2. Establishing the range of land use at the stage of setting out a building

After the building has been constructed, the surveyor prepares an as-built geodetic inventory of the building at the investor's request. At this stage, the surveyor will have to determine the type of land use from the group of built-up and urbanised land and to determine its range. As stated by J. Bielański [17],

the land parcel development plan, which was previously an annex to the investor's application for a decision of the district starost allowing the land to be excluded from production, and the area for which this consent was granted are auxiliary documents only. The as-built inventory is performed in accordance with the actual state of affairs existing in the field, and not in accordance with the state anticipated at the stage of obtaining the building permit. The land is classified in accordance with provisions of the Regulation on land registration.

Examples of provisions applicable in this respect are included in Table 1. 
As J. Bielański [17] writes,

the areas resulting from the as-built inventory of buildings, and thus actually invested, are generally larger than the areas presented as Bp in the land register or shown in the decision of the starost allowing the exclusion from production. This is the reason of often questioning the results of the inventory, as a larger area of invested land results in an increase in property tax, and it may also mean increased fees and charges for the exclusion of land from production.

They are confirmed, among others, by the authors of the publication [18] who analyzed exclusions of land from agricultural production for housing purposes in one of the districts of the Małopolskie voivodeship. The exclusions area was from 125 to $324 \mathrm{~m}^{2}$. Land parcels for which a decision to exclude from agricultural production was issued had areas from 622 to $1471 \mathrm{~m}^{2}$. The authors also examined the exclusion of land from agricultural production in the given cases using the documentation from the as-built inventory of buildings. As the analyzes show, the area of the land use changed since the result of the as-built inventory of buildings is larger than the area of land excluded from agricultural production.

Pursuant to Article 28(1) of the Act [6], if it is found that land has been excluded from production contrary to the provisions of this Act, the contributor of the exclusion shall be charged a double fee. Pursuant to Art. 28. 2, if it is found that land designated in the local development plan for non-agricultural or non-forestry purposes has been excluded from production without the decision referred to in $\mathrm{Ar}$ ticle 11(1) and (2), such decision is issued ex officio, increasing the fee by $10 \%$. As J. Bielański [17] writes,

the second case concerns, inter alia, a situation where an investment has been carried out over a larger area than the area specified in the decision of the starost which authorised the exclusion of land from production and that larger area has been shown as a result of a surveying, post-execution inventory.

The author of the publication [19] points to two approaches used by contractors of surveying works in determining the limits of land use of residential areas at the stage of development of the as-built inventory. As he writes:

some surveying contractors uncritically adhere to the provisions of the decision authorising the exclusion of agricultural land from production and, when determining the limits of residential areas, they strictly adhere to the area specified in that decision.

In this case, the limits of the residential area coincide with the area for which the decision to exclude lands from agricultural production was issued, regardless of the real conditions in the field. In the second case, as the author writes:

there are also supporters of the theory that the decision is irrelevant when determining the limits of land use "residential areas". Important are real conditions in the field and the fact that no legal provision in determining the limits of land use "residential areas" refers to the decision to allow agricultural land to be excluded from production.

This is also indicated by the following author [13].

The proper determination of the type and range of land use at the stage of the as-built inventory of the building will affect the tax assessment. As agricultural 
and forest land are protected, the land with the poorest quality is used for construction purposes. For example, an owner who owns agricultural land pays agricultural tax, and in the event that i. these are agricultural land of class V, VI and VIz as well as wooded and bushy land established on agricultural land is exempt from this fee. In the case of low-quality land in connection with the construction of the building there will be an increase in the tax as it changes from an agricultural tax (or forest tax) to a property tax. Pursuant to Article 6(1) of the Act [20], the tax obligation arises from the first day of the month following the month in which the circumstances justifying the emergence of this obligation arose. Further, as stated in Article 6(2) of the Act [20], if the circumstance on which the tax obligation depends is the existence of a structure or a building or a part thereof, the tax obligation arises on 1 January of the year following the year in which the construction was completed or in which the use of the structure or building or their part was started parts before final finishing.

Depending on what the surveyor determines the type and range of land use as part of the building's as-built inventory, it will then be declared in the notification by the owner of the land parcel for tax calculation purposes. Therefore, when it is set incorrectly, there will be a reduction or increase in the real estate tax due to the disclosure of new land use in the real estate cadastre.

Moreover, as the author [21] writes,

unfortunately, the rules for determining the boundaries of the contours of land uses and their types are too general and do not allow to unambiguously specify the land use of a given piece of earth's surface, and consequently, the tax that should have been calculated, either. These provisions need to be amended.

\section{Analysis of Building Setting Out Documentation}

An analysis was performed for 31 technical documentation sets which resulted from buildings setting out ( 9 from the area of Mińsk district, 9 from the area of Nowy Dwór district, 13 from the area of Warsaw West district). A part of the analysis concerned analysis aimed at the verification of what was the area of the land parcel/parcels on which the building / buildings were set out, what land use was presented before the building setting out and what was the land use presented after setting out. Moreover, the current state of development of the land parcel/parcels (as of July 2020) was examined on the basis of the orthophotomap available on the Geoportal portal and the basic and the cadastral map available on the map portals of particular districts. The research results are presented in Table 2.

The analysis of the building documentation shows that for:

- 21 cases - the Bp land use has been shown on the entire land parcel,

- 8 cases - the Bp land use was shown only on a part of the parcel,

- 2 cases - the Bp land use was shown only under the outline of the building. 


\begin{tabular}{|c|c|c|c|c|}
\hline 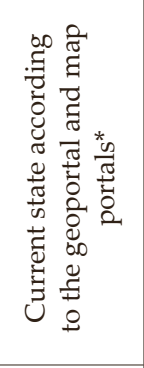 & 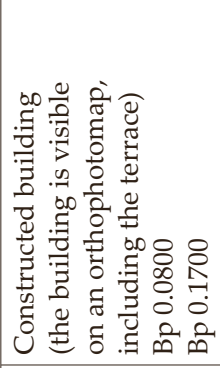 & 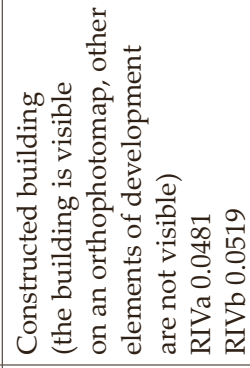 & 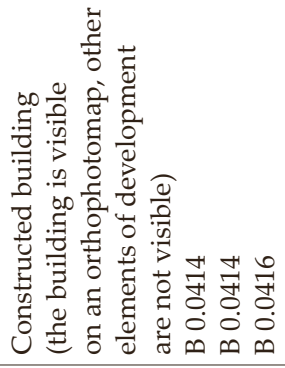 & 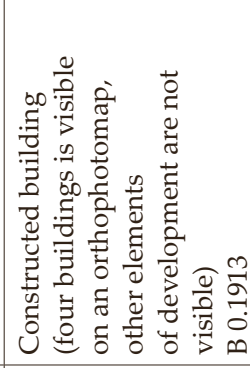 \\
\hline 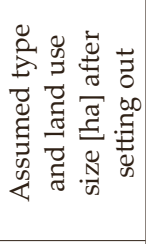 & 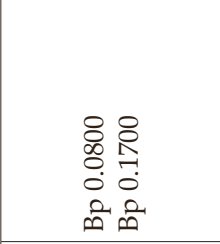 & $\begin{array}{l}8 \\
0 \\
\vdots \\
0 \\
\text { مी }\end{array}$ & 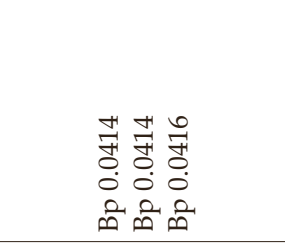 & $\begin{array}{l}\frac{m}{5} \\
\frac{0}{0} \\
0 \\
0\end{array}$ \\
\hline 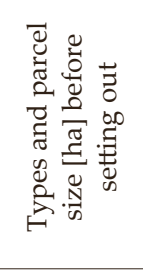 & 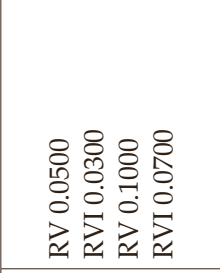 & 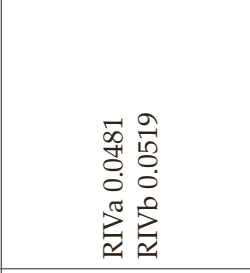 & 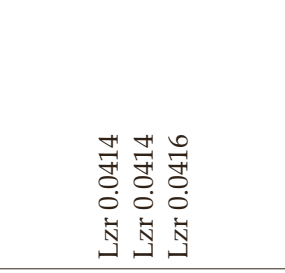 & 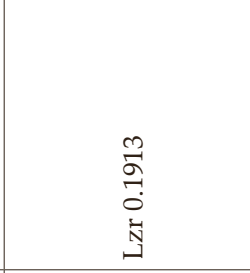 \\
\hline 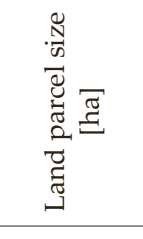 & $\begin{array}{l}8 \\
8 \\
0 \\
0 \\
0 \\
0\end{array}$ & $\begin{array}{l}8 \\
\vdots \\
\vdots \\
\end{array}$ & 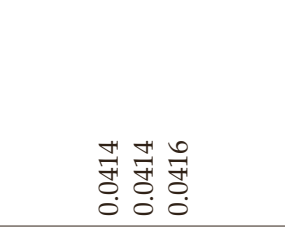 & $\stackrel{m}{\stackrel{m}{\sigma}}$ \\
\hline 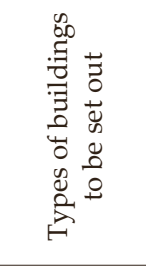 & 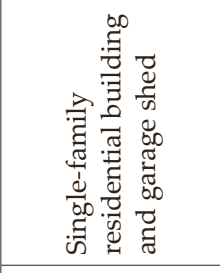 & 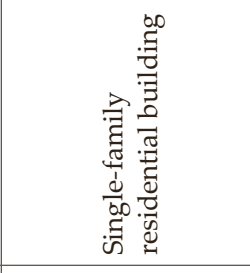 & 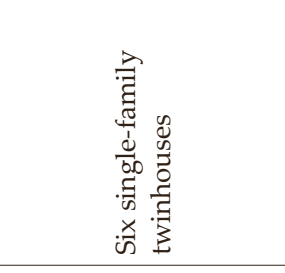 & 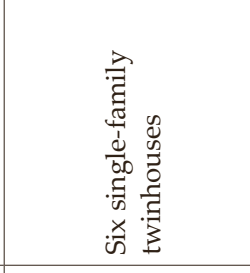 \\
\hline 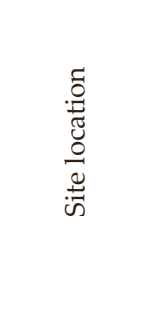 & 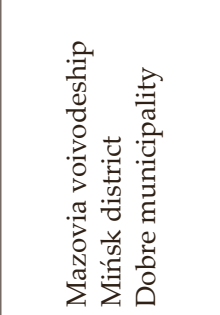 & 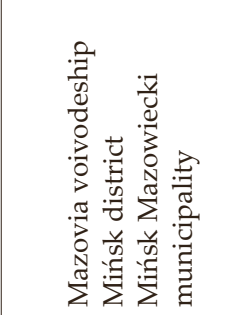 & 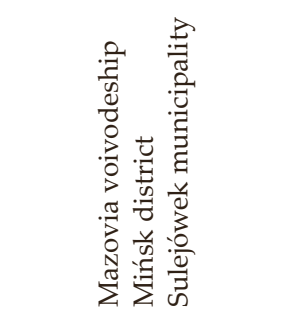 & 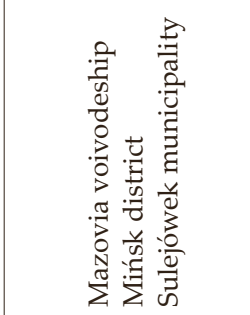 \\
\hline 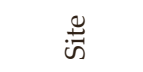 & - & $N$ & $m$ & H \\
\hline
\end{tabular}




\begin{tabular}{|c|c|c|c|c|}
\hline 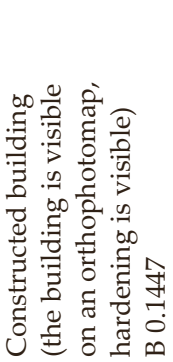 & 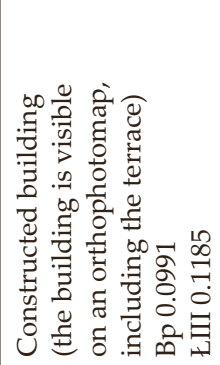 & 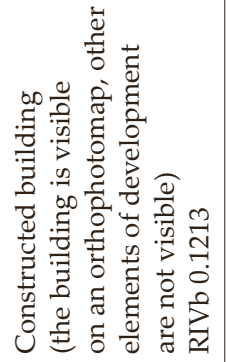 & 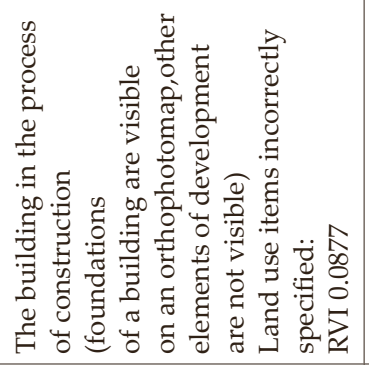 & 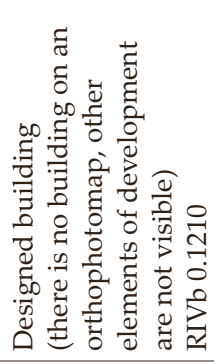 \\
\hline 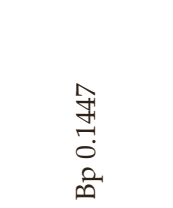 & 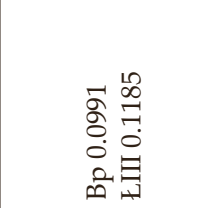 & 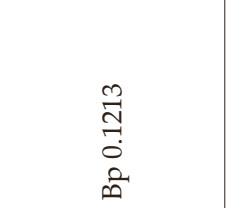 & 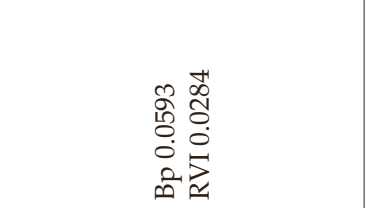 & 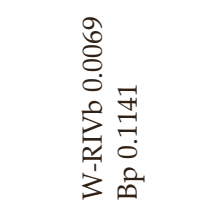 \\
\hline 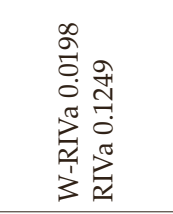 & 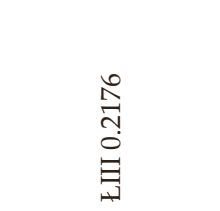 & 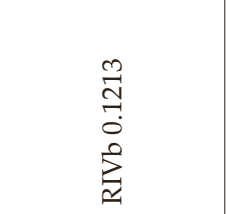 & 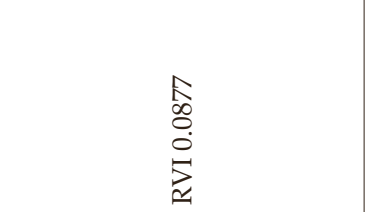 & 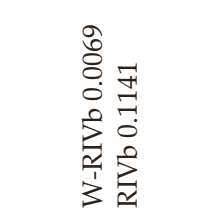 \\
\hline $\begin{array}{l}\stackrel{\text { f }}{ \pm} \\
\stackrel{5}{\circ}\end{array}$ & $\begin{array}{l}\stackrel{0}{ } \\
\text { స̦ } \\
0\end{array}$ & $\begin{array}{l}\stackrel{M}{I} \\
\stackrel{7}{0}\end{array}$ & $\begin{array}{l}\hat{A} \\
\text { Oे } \\
0 \\
0\end{array}$ & 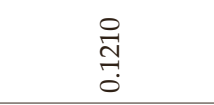 \\
\hline 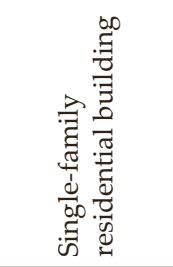 & 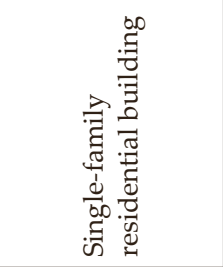 & 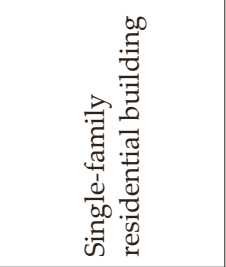 & 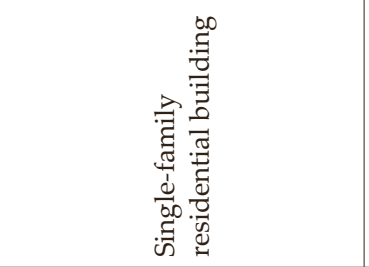 & 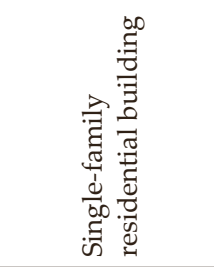 \\
\hline 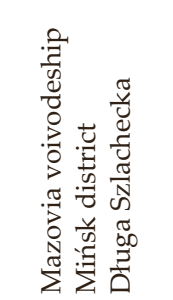 & 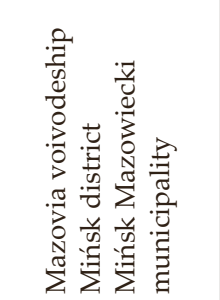 & 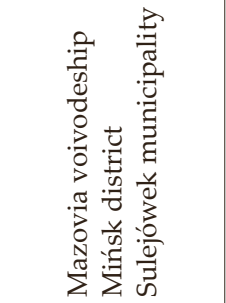 & 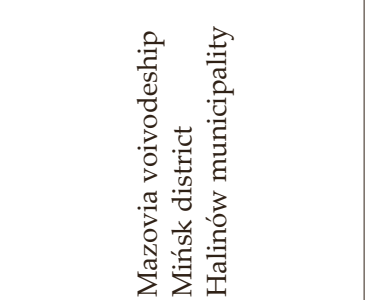 & 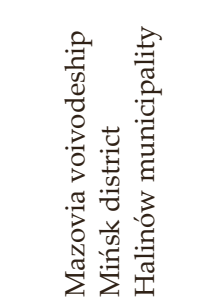 \\
\hline Ln & 6 & $\wedge$ & $\infty$ & $a$ \\
\hline
\end{tabular}




\begin{tabular}{|c|c|c|c|c|}
\hline 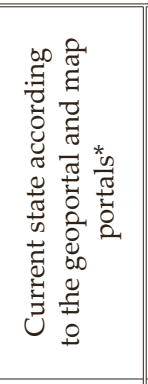 & 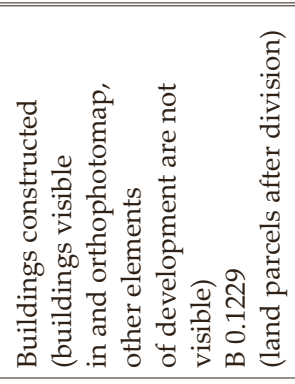 & 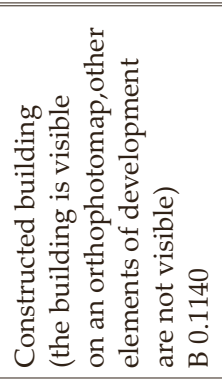 & 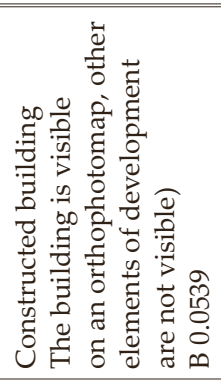 & 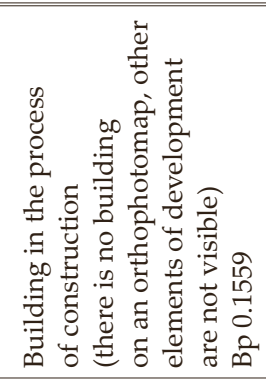 \\
\hline 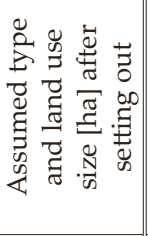 & $\begin{array}{l}\text { సे } \\
0 \\
0 \\
0\end{array}$ & $\begin{array}{l}\text { f } \\
\stackrel{0}{0} \\
\text { की }\end{array}$ & 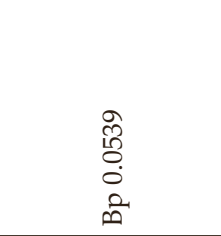 & $\begin{array}{l}\text { مे } \\
\stackrel{2}{0} \\
0 \\
\text { مे }\end{array}$ \\
\hline 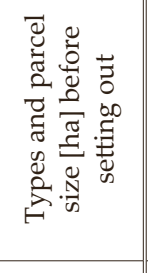 & 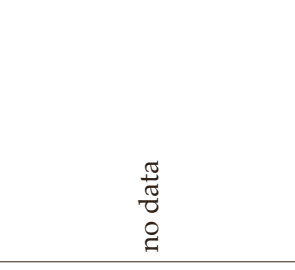 & 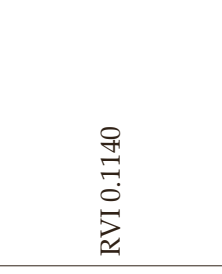 & 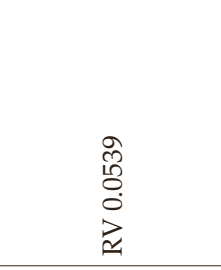 & 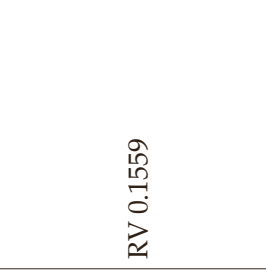 \\
\hline 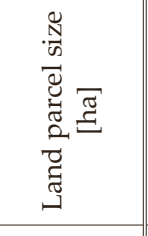 & $\begin{array}{l}\text { సे } \\
\text { ¿े }\end{array}$ & $\begin{array}{l}\text { fit } \\
\text { t. }\end{array}$ & $\begin{array}{l}\text { f } \\
\stackrel{0}{0}\end{array}$ & 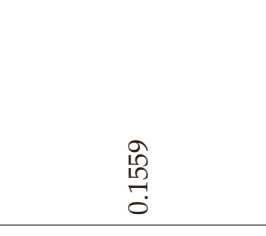 \\
\hline 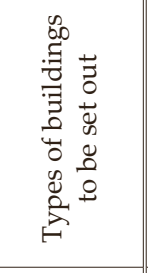 & 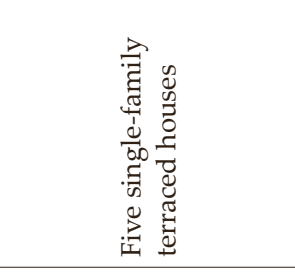 & 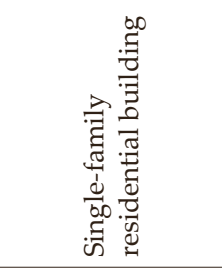 & 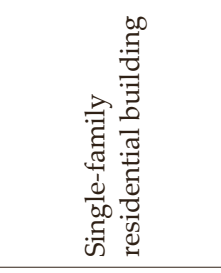 & 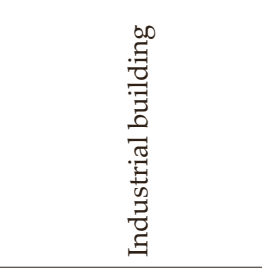 \\
\hline 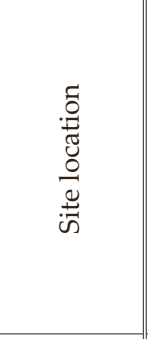 & 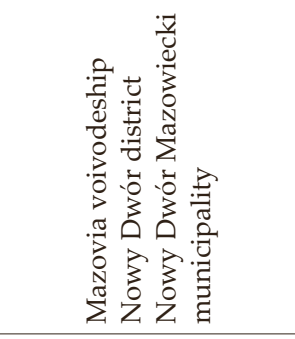 & 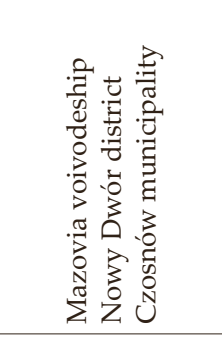 & 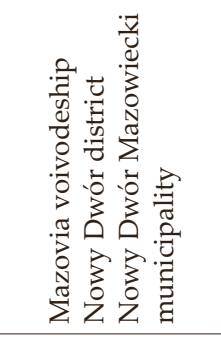 & 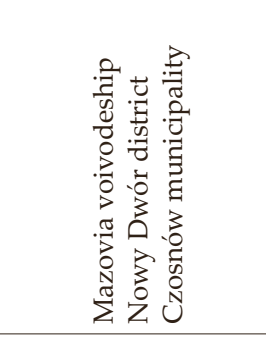 \\
\hline 苛 & $\stackrel{\circ}{\circ}$ & $\exists$ & $\approx$ & $\stackrel{M}{\sim}$ \\
\hline
\end{tabular}




\begin{tabular}{|c|c|c|c|c|}
\hline 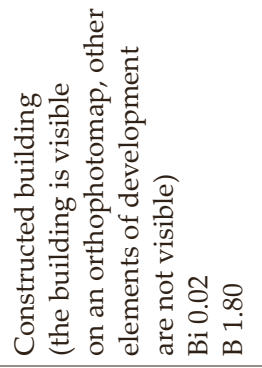 & 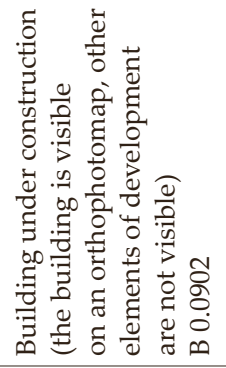 & 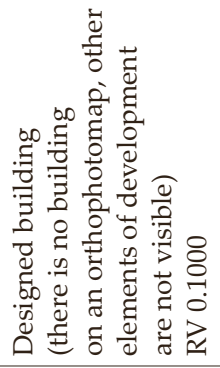 & 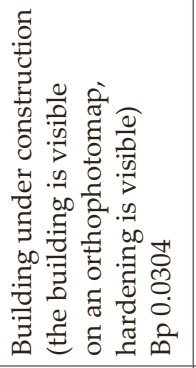 & 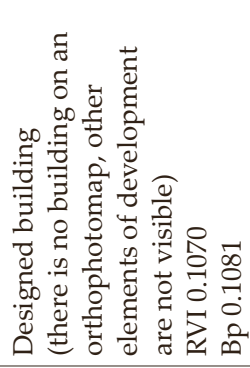 \\
\hline 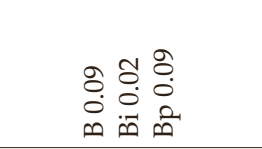 & $\begin{array}{l}\text { ⿵े } \\
\text { oे } \\
0 \\
0 \\
\text { مิ }\end{array}$ & $\begin{array}{l}8 \\
\vdots \\
\vdots \\
0 \\
0 \\
01\end{array}$ & 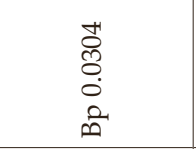 & 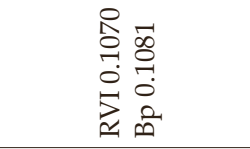 \\
\hline 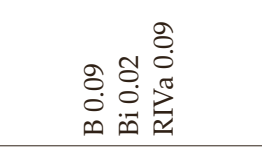 & 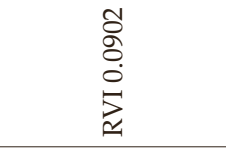 & \begin{tabular}{l}
8 \\
8 \\
\hdashline \\
0 \\
2 \\
\end{tabular} & $\begin{array}{l}\frac{\pi}{\pi} \\
\frac{\pi}{0} \\
\circ \\
\end{array}$ & 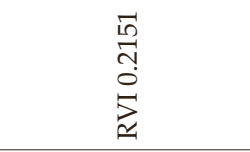 \\
\hline તิ & 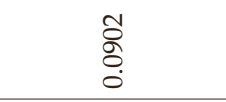 & \begin{tabular}{l}
8 \\
$\vdots$ \\
\hdashline
\end{tabular} & $\begin{array}{l}+ \\
0 \\
0 \\
0 \\
0\end{array}$ & $\begin{array}{l}\overrightarrow{5} \\
\text { तु } \\
0\end{array}$ \\
\hline 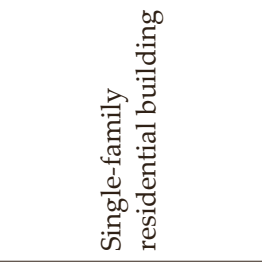 & 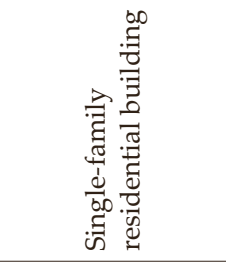 & 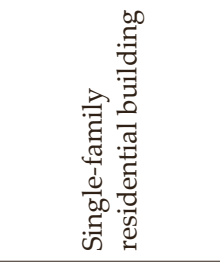 & 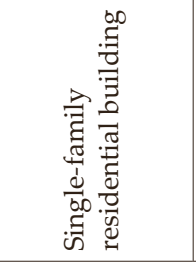 & 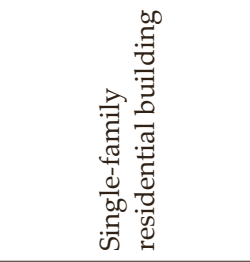 \\
\hline 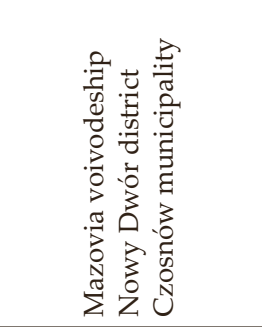 & 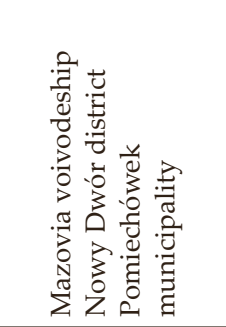 & 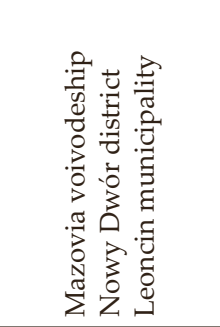 & 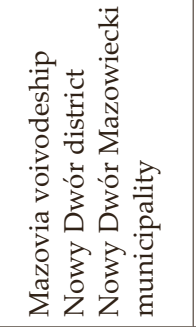 & 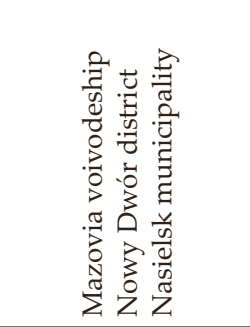 \\
\hline$\underset{\sim}{\sharp}$ & 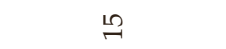 & $\stackrel{\bullet}{\sim}$ & 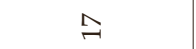 & $\stackrel{\infty}{\sim}$ \\
\hline
\end{tabular}




\begin{tabular}{|c|c|c|c|c|}
\hline 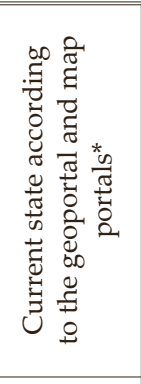 & 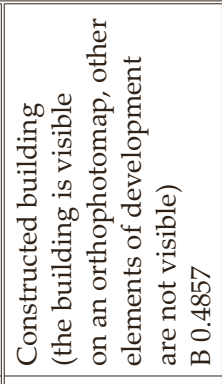 & 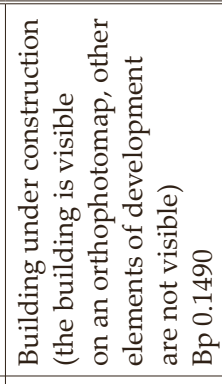 & 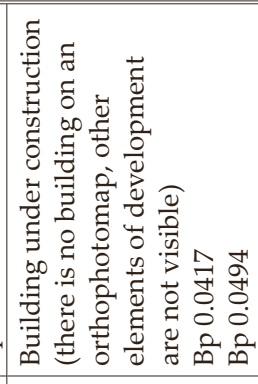 & 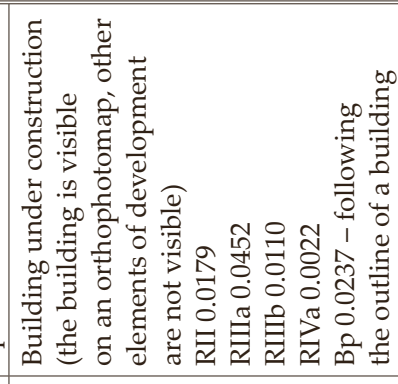 \\
\hline 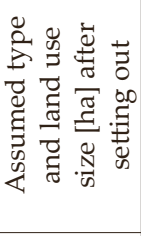 & 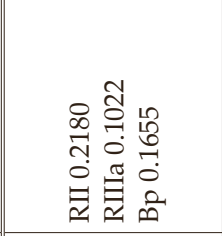 & \begin{tabular}{l}
8 \\
\multirow{2}{0}{} \\
$\stackrel{0}{0}$ \\
2 \\
2
\end{tabular} & 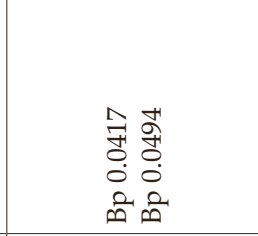 & 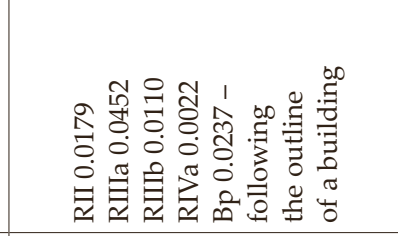 \\
\hline 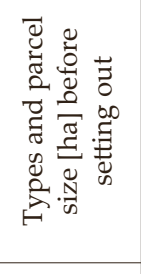 & 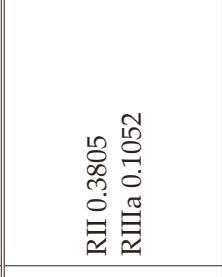 & 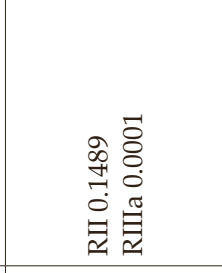 & 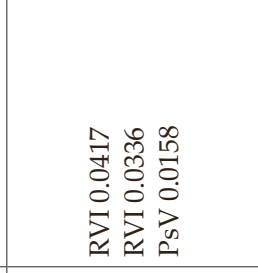 & 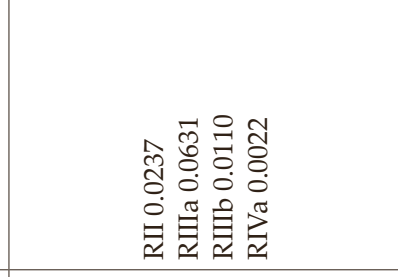 \\
\hline 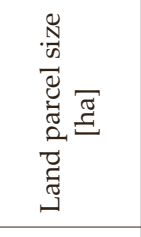 & $\begin{array}{l}\text { 命 } \\
\text { of } \\
0 \\
0\end{array}$ & \begin{tabular}{l}
8 \\
\multirow{7}{7}{} \\
0 \\
0
\end{tabular} & 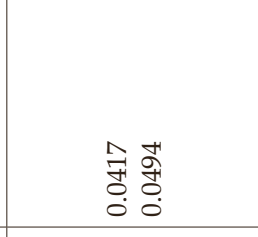 & $\begin{array}{l}8 \\
\stackrel{0}{0} \\
0\end{array}$ \\
\hline 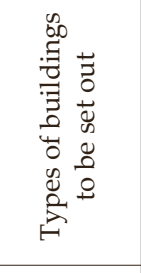 & 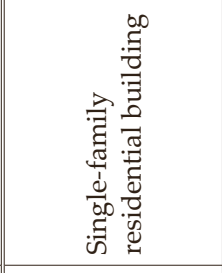 & 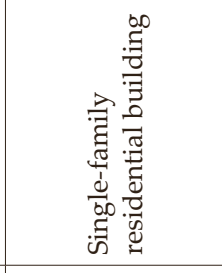 & 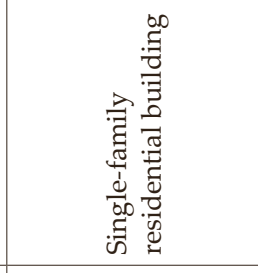 & 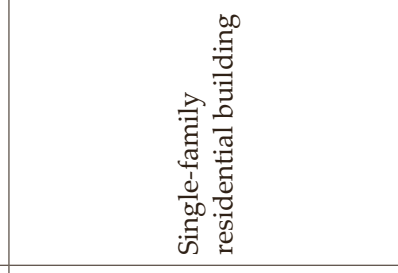 \\
\hline 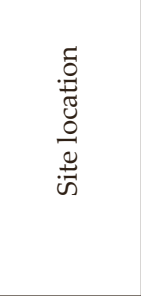 & 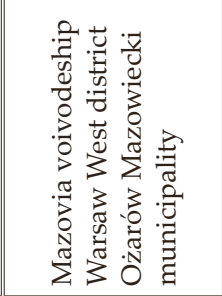 & 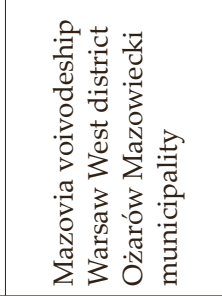 & 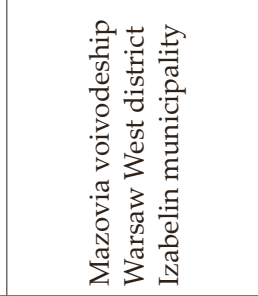 & 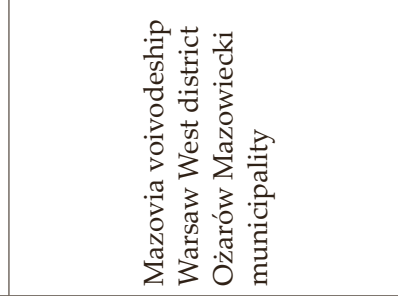 \\
\hline 总 & $\stackrel{9}{-}$ & নి & $\bar{\lambda}$ & ה \\
\hline
\end{tabular}




\begin{tabular}{|c|c|c|c|}
\hline 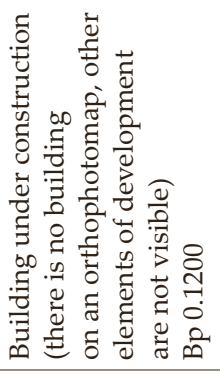 & 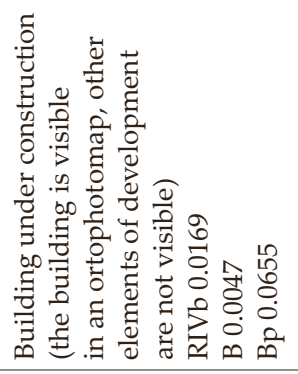 & 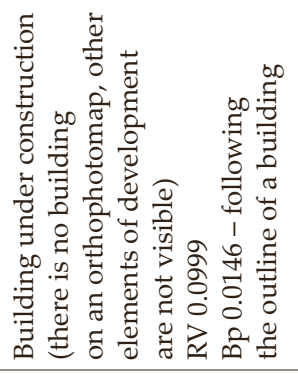 & 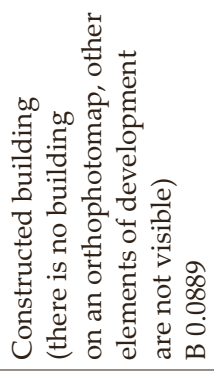 \\
\hline 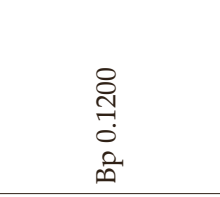 & 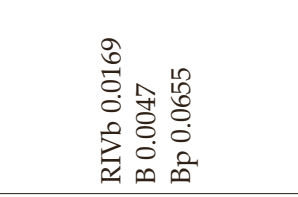 & 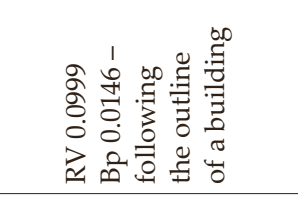 & $\begin{array}{l}\infty \\
\infty \\
0 \\
0 \\
0 \\
0 \\
01\end{array}$ \\
\hline 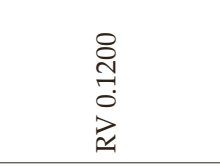 & 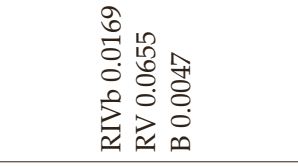 & 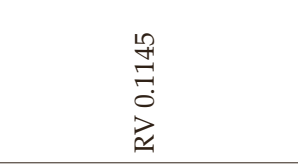 & 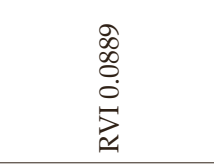 \\
\hline 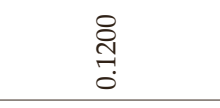 & $\begin{array}{l}\widetilde{1} \\
\text { of } \\
0 \\
0\end{array}$ & $\begin{array}{l}\stackrel{2}{\rightrightarrows} \\
\stackrel{7}{0}\end{array}$ & $\begin{array}{l}\mathscr{2} \\
0 \\
0 \\
0\end{array}$ \\
\hline 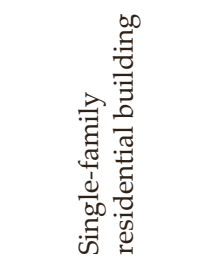 & 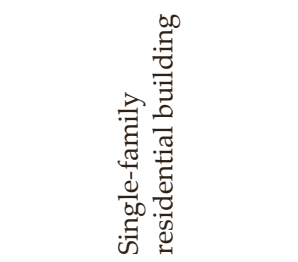 & 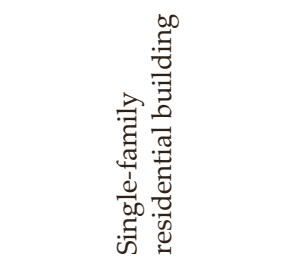 & 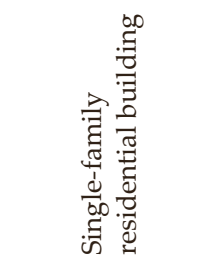 \\
\hline 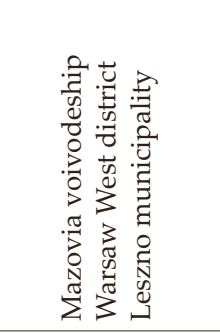 & 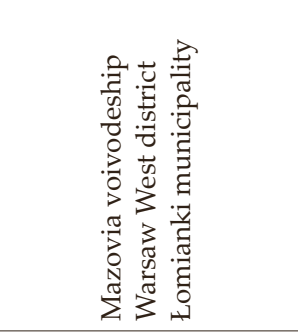 & 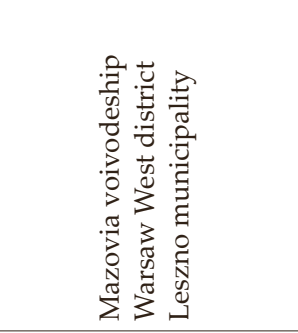 & 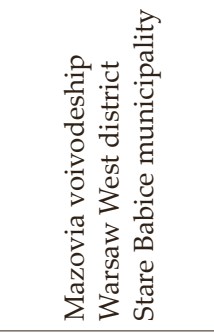 \\
\hline$\ddot{\sim}$ & 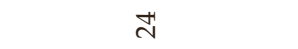 & $\stackrel{\leftrightarrow}{\sim}$ & $\stackrel{\sim}{N}$ \\
\hline
\end{tabular}




\begin{tabular}{|c|c|c|c|}
\hline 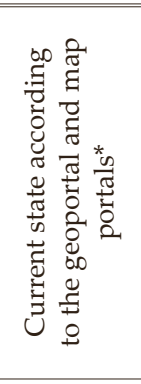 & 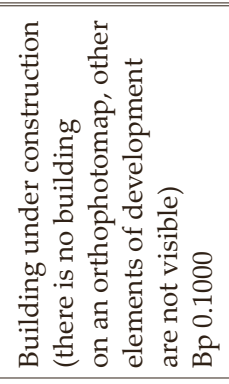 & 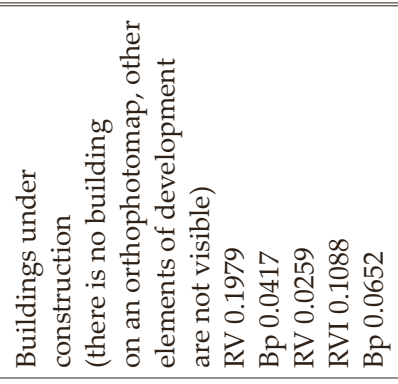 & 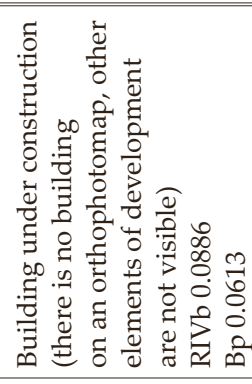 \\
\hline 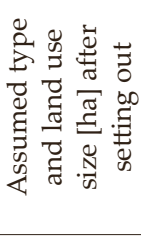 & $\begin{array}{l}8 \\
0 \\
0 \\
0 \\
0\end{array}$ & 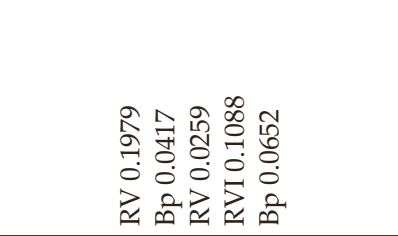 & $\begin{array}{l}\infty \\
\infty \\
\infty \\
0 \\
0 \\
0 \\
0 \\
0 \\
0 \\
0 \\
0\end{array}$ \\
\hline 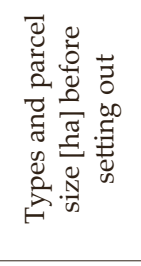 & $\begin{array}{l}8 \\
0 \\
\vdots \\
0 \\
2 \\
\end{array}$ & 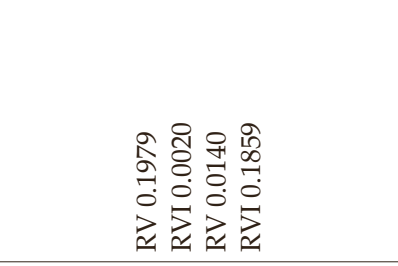 & 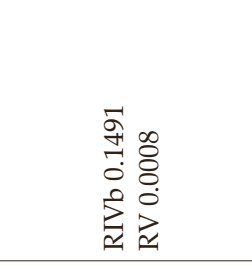 \\
\hline 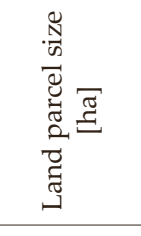 & $\begin{array}{l}8 \\
\stackrel{0}{0} \\
0\end{array}$ & 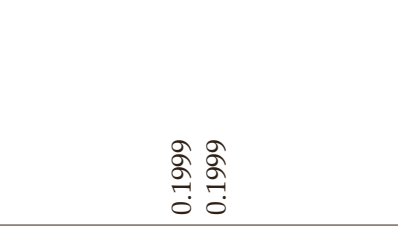 & 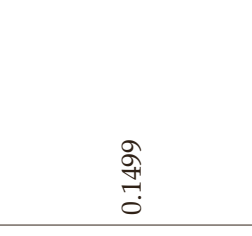 \\
\hline 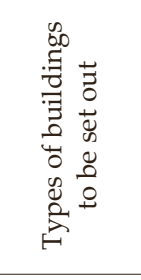 & 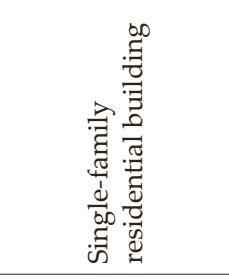 & 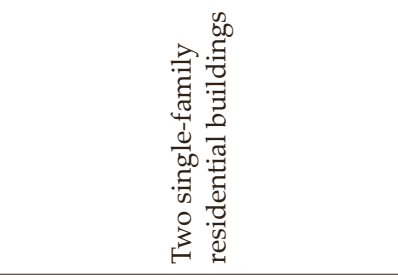 & 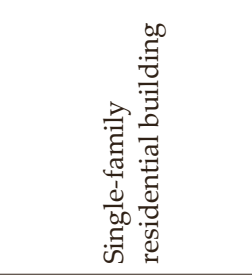 \\
\hline 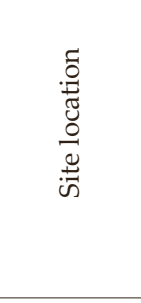 & 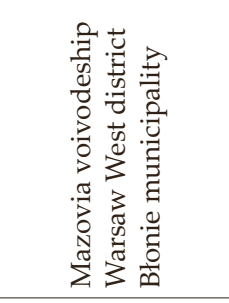 & 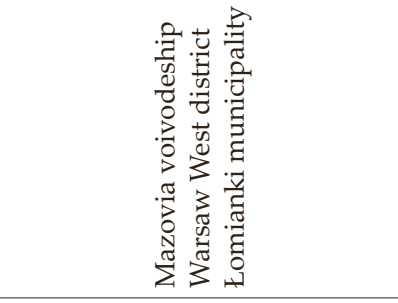 & 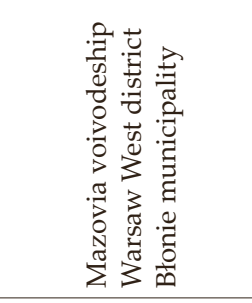 \\
\hline 苛 & ते & $\stackrel{\infty}{\sim}$ & ते \\
\hline
\end{tabular}




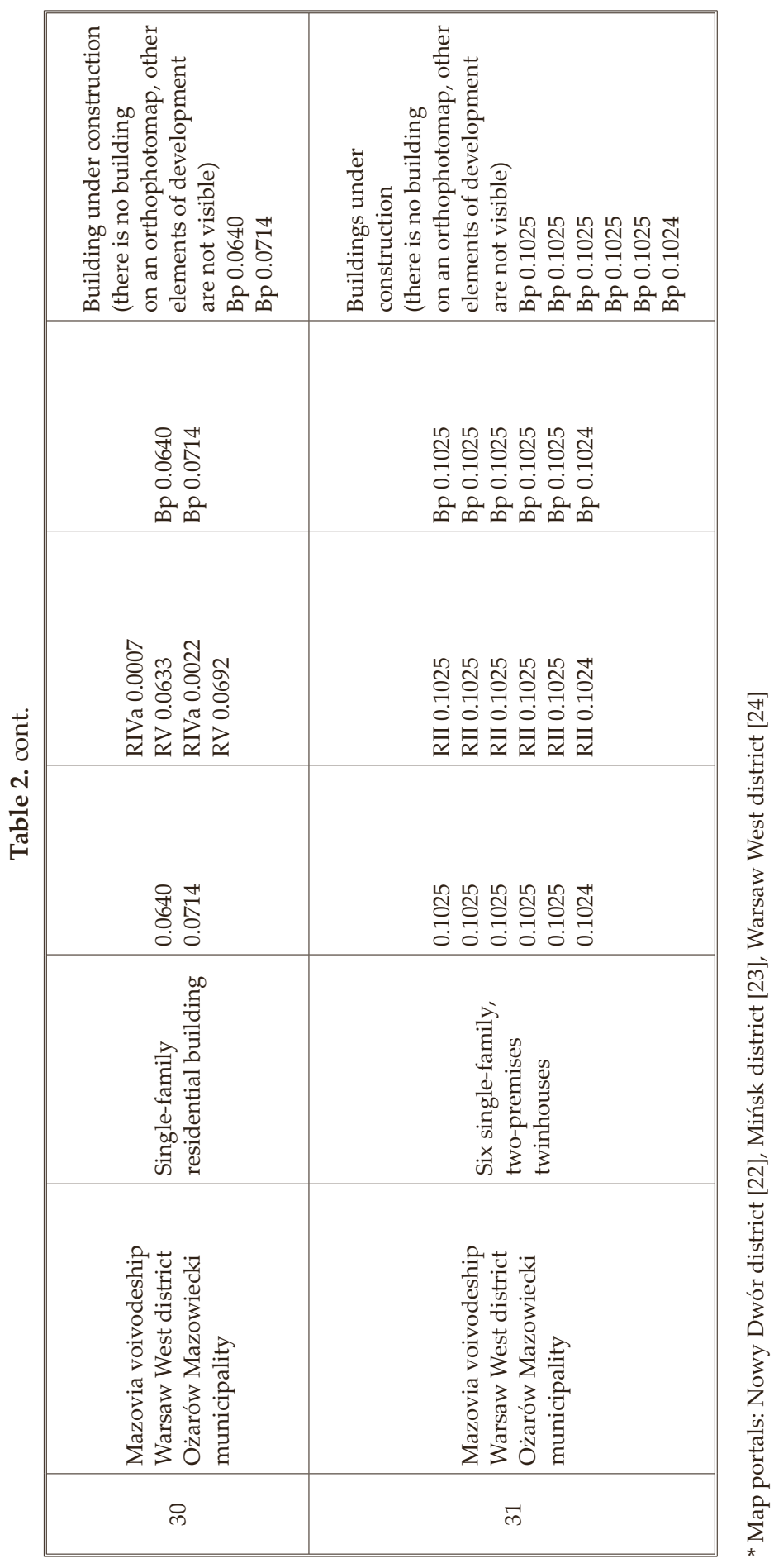


Taking into account the above results, it should be concluded that in the majority of cases, when determining the extent of Bp land use, surveyors did not take into account the decision to allow for excluding the land from agricultural or forest production, taking the Bp land use on the entire parcel, or showing the Bp land use only under the outline of the building.

The analyses of the current state of the parcel development performed on the basis of the orthophotomap available on the Geoportal and the basic and cadastral maps available on the map portals of the individual districts show that for:

- 9 cases - the basic map shows the building under construction; the building is not visible on the orthophotomap, the same land use as in the setting out documentation is specified.

This means that the building has not been constructed yet; the condition after updating in connection with setting out, the same as in the setting out documentation is shown.

- 4 cases - the basic map shows the building under construction; the building is visible on the orthophotomap, the same land use as in the setting out documentation is specified.

This means that the building has been constructed, but on the basic map the building under construction is shown and the condition after updating in connection with setting out, the same as in the setting out documentation is shown, since no as-built inventory of the building has yet been made.

- 2 cases - the basic map shows the constructed building; the building is visible on the orthophotomap, the same land use as in the setting out documentation is specified.

This means that the building has been constructed, however, land use types have not been updated yet due to as-built inventory of the building.

- 2 cases - on the basic map the building is shown; the building is visible on the orthophotomap, the same land use as before setting out is shown.

This means that a building has been constructed, however, no land use update has been made in connection with the building setting out and as-built inventory.

- 8 cases - the basic map shows the constructed building; the building is visible on the orthophotomap, the B land use on the entire parcel is specified.

This means that the building has been constructed, an as-built inventory of the building has been performed, and the state after the update in connection with the as-built inventory of the building is shown.

- 1 case - the basic map shows the constructed building; the building is not visible on the orthophotomap, the B land use is specified on the entire parcel. This results from the fact that the building has been built, the as-built inventory of the building was performed, the state after updating in connection with the as-built inventory of the building is visible, the orthophotomap has not been updated. 
- 1 case - the basic map shows the building under construction; the building is visible on the orthophotomap, the B land use is specified on the entire parcel. This means that the building has been built, an as-built inventory of the building was performed, but the basic map was not updated.

- 1 case - the basic map shows the building under construction; the foundation of the building is visible on the orthophotomap, the same land use as before setting out is incorrectly specified.

This means that the building has been constructed; no updates have been made, probably due to the lack of application by the property owner for changes to be introduced in the land and buildings register, and no as-built inventory has been made of the building.

- 2 cases - on the basic map the designed building is presented; the building is not visible on the orthophotomap, the same land use as before setting out is specified.

This means that the building has not been constructed yet; no updates have been made, probably due to the lack of application by the property owner for changes to be introduced in the land and buildings register.

- 1 case - on the basic map the designed building is presented; the building is not visible on the orthophotomap, the same land use as in the setting out documentation is specified.

This means that the building has not yet been constructed.

It results from performed analyses of the current state of land parcel development that the building under construction is often presented on the basic plan, so the construction process has not been completed and the state after the update is shown due to the building setting out. In many cases, the basic map presents a building under construction and the condition after the update in connection with the as-built inventory of the building. However, there are cases when no update has been made in connection with the building setting out or the as-built inventory; for some cases it results from the lack of application of the property owner concerning changes to be introduced to the land and buildings register. Moreover, very often surveyors set out buildings without reporting it to the district starost, and consequently, they have not submitted the relevant documents to a district geodetic and cartographic documentation centre.

Studies on the effectiveness of the cadastre updating procedures after the setting out of a construction object in the field were the subject of a study presented in [25]. The author randomly selected more than 60 cadastral parcels for which building permits were issued and no cadastre updates in terms of land use were performed. The author made a field inspection and examined whether the construction process has begun, i.e. whether de facto the building setting out documentation is actually submitted by surveyors and has the right effects, i.e. whether the real estate cadastre database is updated. As it results from the author's analysis of the practical 
implementation of the cadastre updating procedure for setting out construction objects in the field, it is not effective. Out of 60 objects inspected, 30 cases were found in which, despite significant progress in the construction process, the real estate cadastre had not been updated.

In turn, the authors of the publication [8] conducted analyzes of the process of excluding arable land from production and changes in the structure of arable land use in the Zwolen district. As the authors point out,

in the studied district, an evident increase in the area of developed and urbanized land was observed at the expense of arable land. Lack of systematic updates of the land and building register was also determined in the scope of data concerning the purpose of land in the study period.

Meanwhile, the authors of the publication [12] assessed the procedure for excluding land from agricultural production in the context of land use disclosure which had been changed in the real estate cadastre. As research shows in the Kazimierz district, 147 applications for excluding land from agricultural production were recorded in the years 2010-2018. The land use Bp was not disclosed for any of the examined land parcel.

\section{Conclusions and Final Remarks}

Studies of the legislation have shown that the land use type to be adopted at the building setting put and as-built inventory stages is precisely defined. But, as far as its scope is concerned, there are no provisions which would specifically define how it should be established. In order to check how the binding legal regulations in this respect are implemented in practice, 31 technical surveys were analysed, which are the result of the building setting out (9 from the area of Mińsk district, 9 from the area of Nowy Dwór district, 13 from the area of Warsaw West district). Within the framework of the analysis, it was verified what was the area of the parcel/ parcels on which the building/buildings were set out, what land use was presented before setting out and what was the land use presented after setting out. Moreover, the current state of development of the land parcel/parcels (as of July 2020) was examined on the basis of the orthophotomap available on the Geoportal and the basic and cadastral maps available on the map portals of particular districts.

As it turns out from the analysis of the building setting out documentation files, in 21 cases - the Bp land use was specified for the entire parcel, in 8 cases - the Bp land use was only specified on part of the land parcel, in 2 cases - the Bp land use was specified only under the outline of the building. Taking into account the above results, it should be concluded that in the majority of cases the surveyors, when determining the extent of the Bp land use, did not take into account the decision to allow for excluding the land from agricultural or forest production, taking the Bp land use on the entire land parcel or specifying the Bp land use only under the outline 
of the building. Therefore, the property tax was reduced or increased due to the disclosure of the new land use in the real estate cadastre.

It results from the analyses of the current state of the land parcel development that the building under construction is often presented on a basic map, so the construction process has not been completed and the state after the update is presented due to the building setting out. In many cases the basic map presents a building under construction and the updated conditions in connection with the as-built inventory of the building. There are, however, cases when no update has been made in connection with the building setting out or preparation of the as-built inventory, for some cases due to the lack of application submitted by the property owner asking to introduce changes to the land and buildings register. Moreover, surveyors have very often set out the buildings without reporting it to the starost, and consequently have not submitted the relevant documents to the district geodetic and cartographic documentation centre.

At a time when there was no obligation to report building setting out, the Supreme Chamber of Control carried out an audit for the period 2009-2011 [26]. The control covered 22 units - city offices with district rights and district starosts in the following voivodeships: Małopolskie, Podlaskie, Podkarpackie, Świętokrzyskie, Wielkopolskie and Zachodniopomorskie, which constituted $6 \%$ of the units of this level of local government administration (379). The objective of the audit was to assess, among others, the procedure for excluding lands from agricultural production, including practices of determining the moment when a non-agricultural use of the land actually begins, as well as updating the land and buildings register with regard to agricultural lands excluded from production and the impact of these changes on the tax registers in municipalities with regard to determining the property tax. The audit proved that the land and buildings register was not systematically updated in terms of land use data. According to the report, changes in the register in most cases were made only in connection with the completion of (often long-term) construction works. In the majority of cases, the disclosure of the changed land use in the register, in connection with the exclusion of lands from agricultural production, took place on the basis of the submitted surveying documentation of as-built inventories in connection with the completion of construction works. This resulted in the collection of agricultural tax by municipalities on lands which was actually used for other purposes, e.g. housing or industry, instead of collection of the usually higher property tax. The author of [27] also points to this problem. As stated in the report [26], during the period of the investment, the municipalities' incomes from the agricultural tax on agricultural lands equalled to only $12 \%$ of the incomes that could be obtained from the property tax. The stated lapse of time between the date of the final decision allowing the land to be excluded from production and the introduction of a change in the records was 4 years (as an average) in the controlled group of cases, and in the extreme case - it even equalled 19 years. 
In the current state of law, when there is no obligation to notify the relevant authorities of building setting out, the Bp land use updating process may not be carried out, as only the owner will be obliged to notify any changes in this respect. As the inspection of the Supreme Chamber of Control [26] has shown, the obligation laid down in Article 22(2) of the Act [1] was not enforced within the inspection period, and the sanction imposed by Article 48(1)(5) of the aforementioned Act was not applied.

\section{References}

[1] Ustawa z dnia 17 maja 1989 r. Prawo Geodezyjne i Kartograficzne, tekst jednolity z dnia 28 stycznia 2020 r. Dz.U. 2020, poz. 276 [Act of 17 May 1989 Geodesic and Cartographic Law, consolidated text of 28 January 2020. Journal of Laws of 2020, item 276].

[2] Ustawa z dnia 7 lipca 1994 r. Prawo budowlane, tekst jednolity z dnia 7 lipca 2020 r. Dz.U. 2020, poz. 1333 [Act of 7 July 1994, The Building Law, consolidated text of 7 July 2020. Journal of Laws of 2020, item 1333].

[3] Rozporzadzenie Ministra Rozwoju Regionalnego i Budownictwa z dnia 29 marca 2001 r. w sprawie ewidencji gruntów i budynków, tekst jednolity z dnia 3 stycznia 2019 r. Dz.U. 2019, poz. 393 [Regulation of the Minister of Regional Development and Construction of 29 March 2001 on land and buildings register, consolidated text of 3 January 2019. Journal of Laws of 2019, item 393].

[4] Wyrok Wojewódzkiego Sąu Administracyjnego we Wrocławiu - sygnatura akt II SA/Wr 503/15 z dnia 28 października 2015 r. [Judgment of the Voivodeship Administrative Court in Wroctaw - Case No II SA/Wr 503/15 of 28 October 2015].

[5] Benduch P., Pęska A.: Land and Buildings Register Data Change as a Result of Construction Process. Geomatics and Environmental Engineering, vol. 10, no. 3, 2016, pp. 75-86.

[6] Ustawa z dnia 3 lutego 1995 r. o ochronie gruntów rolnych i leśnych, tekst jednolity z dnia 26 maja 2017 r. Dz.U. 2017, poz. 1161 [Act of 3 February 1995 on protection of arable and forests lands, consolidated text of 26 May 2017. Journal of Laws of 2017, item 1161].

[7] Prus B.: Exclusion of lands from agricultural production and urban pressure - case study. Geomatics, Landmanagement and Landscape, no. 4, 2016, pp. 169-182.

[8] Bielska A., Turek A.: Analysis of the needs for updates of the land and building register considering the procedure of exclusion of agricultural land from production. Infrastruktura i Ekologia Terenów Wiejskich, nr IV/3, 2016, pp. 1633-1644.

[9] Całka B., Bielecka E.: Analiza procesu wyłązeń gruntów z produkcji rolnej i leśnej na terenach wiejskich. Infrastruktura i Ekologia Terenów Wiejskich, nr 2/III, 2012, pp.163-173. 
[10] Bieda A., Jasińska E., Preweda E.: Surveying protection of agricultural land in Poland. [in:] 9th International Conference "Environmental Engineering", 22-23 May 2014, Vilnius, Lithuania: Selected Papers, Vilnius Gediminas Technical University Press Technika, 2014. https://doi.org/10.3846/enviro.2014.192.

[11] Kwartnik-Pruc A., Parzych P., Bydłosz J.: Problemy przeznaczania, na terenach wsi, gruntów rolnych i leśnych na cele inwestycyjne. Infrastruktura i Ekologia Terenów Wiejskich, nr 4, 2011, pp. 97-108.

[12] Pęska-Siwik A., Reczyńska J.: Evaluation of the procedure for excluding land from agricultural production in the context of disclosure of changes in the use of land in land and building records. Infrastruktura i Ekologia Terenów Wiejskich, nr III/1, 2019, pp. 181-195.

[13] Benduch P.: Selected problems of law determining the extent and types of land uses. Infrastruktura i Ekologia Terenów Wiejskich, nr III/1, 2017, pp. 999-1015.

[14] Maćkiewicz B., Motek P.: Wyłaczenia gruntów rolnych z produkcji rolnej a dochody gmin z podatku od nieruchomości. Rozwój Regionalny i Polityka Regionalna, nr 28, 2014, pp. 69-77.

[15] Kwartnik-Pruc A.: Exclusion of Land from Agricultural and Forestry Production. Practical Problems of the Procedure. Geomatics and Environmental Engineering, vol. 5, no. 3, 2011, pp. 69-77.

[16] Rozporzadzenie Ministra Infrastruktury z dnia 12 kwietnia 2002 r. w sprawie warunków technicznych, jakim powinny odpowiadać budynki i ich usytuowanie, tekst jednolity z dnia 8 kwietnia 2019 r. Dz.U. 2019, poz. 1065 [Regulation of the Minister of Infrastructure of 12 April 2002 on technical conditions to be met by buildings and their location, consolidated text of 8 April 2019. Journal of Laws of 2019, item 1065].

[17] Bielański J.: Kwalifikowanie gruntów do poszczególnych rodzajów użytków gruntowych [training materials from the training "Amendment of the law in the field of geodesy and cartography" under the patronage of the Surveyor General of Poland conducted by the Association of Polish Surveyors, the Team of Property Appraisers, Rynia, 20-22 October 2014].

[18] Gałuszka Z., Hanus P.: Analiza wyłaczenia gruntów z produkcji rolnej w kontekście inwentaryzacji powykonawczej budynku. Acta Scientifica Academiae Ostroviensis, Wyższa Szkoła Biznesu i Przedsiębiorczości w Ostrowcu Świętokrzyskim, issue 35-36, 2011, pp. 12-19.

[19] Mierzwiak H., Pręgowski D.: Problemy przy definiowaniu użytku "tereny mieszkaniowe". Przegląd Geodezyjny, R. 88, z. 2, 2016, pp. 28-30.

[20] Ustawa z dnia 12 stycznia 1991 r. o podatkach $i$ opłatach lokalnych, tekst jednolity z dnia 16 maja 2019 r. Dz.U. 2019, poz. 1170 [Act of 12 January 1991 on taxes and local fees, consolidated text of 16 May 2019. Journal of Laws of 2019, item 1170]. 
[21] Benduch P.: Problematic aspects of determining the surface area of grounds, buildings and premises for cadastre and real estate taxation purposes. [in:] "Environmental Engineering" $10^{\text {th }}$ International Conference. Vilnius Gediminas Technical University, Lithuania, 27-28 April 2017. Selected papers. https://doi.org/10.3846/ enviro.2017.163.

[22] Geoportal Powiatu Nowodworskiego. https://nowodworski.geoportal2.pl [access: 1.07.2020].

[23] System Informacji Przestrzennej Powiatu Mińskiego. http://www.minski. e-mapa.net/ [access: 1.07.2020].

[24] Portal Mapowy Powiatu Warszawskiego Zachodniego. https://webewid. pwz.pl/e-uslugi/portal-mapowy [access: 1.07.2020].

[25] Karabin M.: Issues related to updating the cadastre in the course of building process. [in:] 19 ${ }^{\text {th }}$ International Multidisciplinary Scientific GeoConference. SGEM 2019, 30 June - 6 July 2019, Albena, Bulgaria. Conference proceedings. Vol. 19, Informatics, geoinformatics and remote sensing. Iss. 2.2, Geodesy and mine surveying. Photogrammetry and remote sensing. Cartography and GIS, STEF92 Technology, Sofia 2019, pp. 183-188. https://doi.org/10.5593/sgem2019/2.2/S09.023.

[26] Informacja o wynikach kontroli Najwyższej Izby Kontroli pt. „Wyłaczanie gruntów z produkcji rolniczej $i$ jego skutki dla ewidencji podatkowej w gminach $w$ latach 2007-2012", nr kontroli P/11/141, nr ewidencyjny 156/2012/P11141/LKR [Information on the results of the Supreme Chamber of Control: "Exclusion of land from agricultural production and its effects on tax records in municipalities in the period 2007-2012", control number P/11/141, registration number 156/2012/ P11141/LKR].

[27] Dawid L.: Problemy z wykorzystywaniem danych z katastru nieruchomości do celów podatkowych na przykładzie gminy wiejskiej Będzino. Infrastruktura i Ekologia Terenów Wiejskich, nr 1/III, 2012, pp. 7-17. 